\title{
ANALISIS BAHASA PADA FEATURE DALAM SURAT KABAR JAWA POS.COM
}

\author{
Hayyin Shofiyatin ${ }^{1}$, Indrya Mulyaningsih ${ }^{\mathbf{1}}$, dan Itaristanti $^{2}$ \\ ${ }^{1}$ IAIN Syekh Nurjati Cirebon \\ Email: hayyin12@gmail.com
}

\begin{abstract}
Abstrak
Penelitian bertujuan untuk menemukan karakteristik bahasa yang digunakan feature pada surat kabar Jawa Pos.com dengan menganalisis gaya bahasa dan pola penulisan. Penelitian dilakukan karena terdapat perbedaan antara teori dan bukti di lapangan, yakni penulisan feature oleh Jawa Pos.com tidak sama dengan teori. Analisis pada feature ini menggunakan metode analisis bahasa jenis padan. Penelitian termasuk ke dalam jenis kualitatif deskriptif, yakni menjelaskan suatu fenomena dalam bentuk deskripsi. Hasil penelitian menunjukkan feature pada surat kabar Jawa Pos.com memiliki karakteristik yang berbeda dari teori yang telah ada. Seperti dapat dilihat pada struktur yang membentuk pola tidak sama dengan teori. Yakni, karakteristik masing-masing struktur tidak terpenuhi. Hal ini secara ilmiah tidak menjadi masalah, karena hakikatnya sebuah karangan tidak dibatasi bahkan lebih baik menggunakan imajinasi yang luas.
\end{abstract}

Kata kunci: Analisis, Feature, Gaya Bahasa, Pola, Surat Kabar

\begin{abstract}
.The study aims to find the characteristics of the language used by Jawa Pos.com newspaper features by analyzing the style of language and writing patterns. The study was conducted because there are differences between theory and evidence in the field, namely feature writing by Jawa Pos.com is not the same as theory. The analysis of this feature uses the same type of language analysis method. Research is included in the type of descriptive qualitative, which describes a phenomenon in the form of a description. The results of the study show features in the Jawa Pos.com newspaper having different characteristics from the existing theories. As can be seen in the structure that forms a pattern not the same as the theory. Namely, the characteristics of each structure are not fulfilled. This is not scientifically a problem, because the essence of an unrestricted essay is even better to use a broad imagination.
\end{abstract}

Keywords: Analysis, Feature, Language Style, Pattern, Newspaper.

\section{PENDAHULUAN}

Surat kabar atau lebih sering disebut koran adalah salah satu jenis media komunikasi massa. Artinya, koran merupakan organisasi media yang memproduksi dan menyebarkan pesan kepada publik. Pesan tersebut biasanya dicari, digunakan, dan dikonsumsi oleh masyarakat secara luas (Daryanto, 2016:115). Berbagai konten pada surat kabar menjadi salah satu hal yang paling diperhatikan. Secara umum surat kabar memuat berita tentang pendidikan, ekonomi, politik, olahraga, dan sosial. Berita-berita tersebut disampaikan dengan gaya yang berbeda-beda. Sebagian mengedepankan berita yang ditulis sesuai bahasa jurnalis dan ada juga yang ditulis seperti alur cerita 
yang biasa disebut feature. Salah satu yang menjadi ketertarikan darifeature. karena disajikan dengan gaya yang dibubuhi unsur human-touch (Kusumaningrat, 2016:219).

Berita feature umumnya ditulis untuk memberi hiburan sebagai bacaan yang ringan dan mendidik. Feature dapat digambarkan sebagai berita tambahan setelah pembaca atau jika istilah seminar adalah break atau jeda (Barus, 2010:172). Jawa Pos.com sebagai surat kabar yang penyebarannya sudah cukup luas, dapat menjadi acuan dalam segi penyajian. Tulisan atau bahasa pada media massa adalah hal yang paling mendominasi atau paling berpengaruh. Oleh karena itu, kajian dalam penyajian tulisan ini penting dilakukan. Istilah yang digunakan dalam penelitian ini adalah analisis terhadap bahasa yang digunakan Feature.

Penulisan feature pada dasarnya harus aktual dan informatif, namun juga harus menghidupkan suatu berita baik peristiwa atau kisah pribadi seseorang. Feature dalam surat kabar ditulis berbeda dari jenis berita lainnya, atau dapat disebut seperti cerita. Berdasarkan hal tersebut, maka rumusan masalah dalam penelitian ini adalah Bagaimana penggunaan gaya bahasa pada feature dalam surat kabar Jawa Pos.com Edisi November 2018? Dan Bagaimana pola penulisan bahasa pada feature dalam surat kabar Jawa Pos.com Edisi November 2018? Penelitian bertujuan mendeskripsikan penggunaan bahasa pada feature dari segi gaya bahasa dan pola penulisan pada feature dalam surat kabar Jawa Pos.com Edisi November 2018.

Menurut sebuah penelitian yang dilakukan (Cahyo, 2009) berita feature dapat menjadi sebuah media dakwah. Penelitian dengan judul Berita Feature sebagai Metode Dakwah (Studi terhadap Rubrik "Silaturahim" di QA Propetic Parenting Magazine, itu memperoleh hasil dalam berita feature tersebut banyak mengandung kelebihan sebagai metode dakwah. Metode dakwah yang disampaikan melalui feature dapat dikatakan tepat. Hal tersebut mengingat feature adalah tulisan yang mudah dipahami, sehingga pembaca dapat lebih mengerti dengan maksud yang ingin dituju.

Berdakwah adalah salah satu jalan menuju kebaikan. Suatu kebaikan akan diterima dari seorang yang memberi kabar, sebagaimana Allah juga memerintah makhluk berbuat baik melalui kabar. Seperti yang dijelaskan dalam Alquran Surah Al-Isra' ayat 9 yang memiliki arti sesungguhnya Alquran ini memberikan petunjuk kepada (jalan) yang lebih lurus dan kabar gembira kepada orangorang mukmin yang mengerjakan amal saleh bahwa bagi mereka pahala yang besar. Pada akhirnya, penelitian ini juga ingin menyampaikan bahwa surat kabar sebagai media pemberi kabar juga dapat menjadi jalan kebaikan. Menemukan karakteristik ataupun pola dalam penulisan feature ini diharapkan dapat memberi ilmu baru pada jurnalis dan para penuntut ilmu lainnya. Penelitian untuk menemukan pola penulisan bahasa dilakukan pada banyak jenis tulisan, feature adalah salah satu jenis yang diteliti.

Penelitian juga dilakukan oleh Ulfah Mey Lida dan Ida Zulaeha yang diterbitkan oleh Journal Indonesian Language Education and Literature Vol. 3, No. 1, Desember 2017 yang berjudul "Pola Penelaran dalam Karangan Argumentasi pada Siswa Tahap Operasi Formal". Penelitian ini bertujuan untuk menemukan dan mendeskripsikan pola argumen dalam karangan argumentasi siswa terhadap operasi formal dengan model analisis dari Miles dan Huberman. Hasil temuan menunjukkan daya pikir siswa pada tahap operasi formal sudah sangat kreatif dan variatif (Mey \& Zulaeha, 2017). Persamaan dengan penelitian yang akan dilakukan yaitu sama-sama mencari pola. Sementara perbedaan jelas terdapat pada cara analisis dan objek yang diteliti.

Penelitian dengan wilayah kajian jurnalistik ini tetap memberi kontribusi pada dunia pendidikan. Berita sebagai salah satu bahan ajar yang terdapat di kelas delapan Sekolah Menengah Pertama yakni pada KD KD 3.1 dan 3.2 kurikulum 2013. Kompetensi Dasar (KD) tersebut berbunyi (3.1) Mengidentifikasi unsur-unsur teks berita (membanggakan dan memotivasi) yang didengar dan dibaca, (4.1) Menyimpulkan isi berita (membangun dan memotivasi) yang dibaca dan didengar. Pembelajaran tersebut berupa pengetahuan mengenai karangan dan berita. Karangan bersifat dinamis sehingga sebuah teori tidak selalu menjadi patokan. Karangan sebagai hasil asli manusia bersifat dinamis, juga berlandaskan pada manusia memiliki sifat kreatif. Namun di sini, kekreatifan yang 
dapat dilakukan hanya sebatas dari tata tulis, unsur human interest sebagai ciri khas tidak dapat hilang.

Melalui menulis berita atau mengarang sebuah tulisan, siswa berarti telah berkarya yang termasuk dalam C6 (cogtitive 6). Kemampuan siswa ini termasuk dalam kegiatan HOTS. Dalam Taksonomi Bloom revisi, HOTS termasuk ke dalam kemampuan kognitif pada tingkat penerapan, analisis, evaluasi, dan inovasi (Mulyaningsih \& Itaristanti, 2018). Berdasarkan hal tersebut, jika siswa telah membuat suatu karangan berarti telah melakukan HOTS atau Higher Order Thinking Skills.

\section{METODE}

Penelitian ini bertujuan untuk menemukan bahasa dan pola penulisan feature di Surat Kabar Jawa Pos.com Edisi November 2018. Oleh karena itu, pendekatan yang digunakan adalah kualitatif dengan model induksi. Pengambilan sampel dilakukan secara random, yakni secara acak mengambil dari masing-masing jenis feature. Terdapat sebelas berita feature dari enam jenis feature yang dianalisis. Penelitian jenis kualitatif ini menggunakan metode analisis bahasa. Metode yang digunakan yaitu padan, yakni analisis bahasa dengan unsur penentu yang berada di luar bahasa. Unsur atau alat penentu tersebut adalah 1) referen, 2) ortografis, 3) pragmatis, 4) artikulatoris, dan 5) translasional (Sudaryanto, 2015: 13). Sementara itu dalam penelitian ini menggunakan alat penentu referen, yakni berupa teori gaya bahasa dan struktur atau pola feature.

Penelitian ini menggunakan teknik pengumpulan data dengan dua cara yakni; observasi dan dokumen. Menurut Nasution (dalam Sugiyono 2016: 64) teknik pengumpulan data melalui observasi adalah dasar segala ilmu pengetahuan. Seorang ilmuan akan mengkaji sesuatu berdasarkan data, data tersebut diperoleh dari observasi. Observasi data akan dilakukan selama satu bulan yaitu November 2018. Data yang diperoleh kemudian menjadi sebuah dokumen, hasil penelitian melalui observasi akan lebih kredibel atau valid dengan dicatat dalam sebuah dokumen. Data yang diperoleh melalui metode dokumenter pada penelitian kali ini disebut dokumen ekstern. Dokumen ekstern ialah bahanbahan informasi yang dikeluarkan suatu lembaga, seperti majalah, buletin, surat kabar, atau pemberitahuan lain (Burhan, 2012: 124).

Secara lebih sederhana teknik analisis dilakukan dalam empat tahap, yaitu (1) mengklarifikasi data feature ke dalam kartu data yang telah disesuaikan dengan masing-masing jenis, (2) Mengidentifikasi data feature berdasarkan gaya bahasa dan pola yang dibenturkan dengan teori, (3) menginterpretasikan hasil identifikasi untuk memperoleh tafsiran sebagai hasil, dan (4) mendeskripsikan hasil penelitian sesuai dengan rumusan masalah.

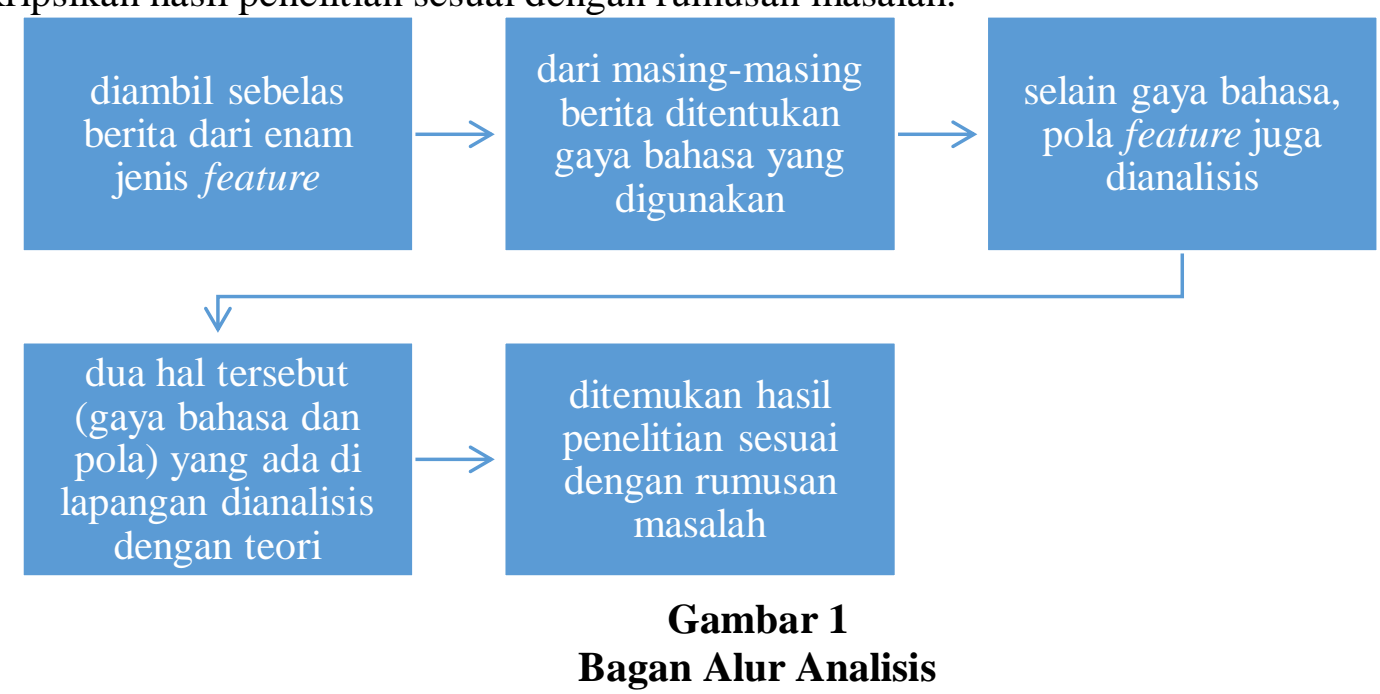




\section{HASIL PENELITIAN DAN PEMBAHASAN}

Beberapa ilmuan menyampaikan perbedaan pendapat mengenai jenis-jenis gaya bahasa. Perbedaan jenis-jenis yang dipaparkan tersebut sesuai dengan sudut pandang masing-masing ilmuan. Seperti yang disampaikan Henry Guntur Tarigan dan Gorys Keraf masing-masing memaparkan jenis gaya bahasa dengan sudut pandang yang berbeda-beda. Henry menyebutkan secara garis besar terdapat empat ragam atau jenis gaya bahasa, yakni gaya bahasa perbandingan, gaya bahasa pertentangan, gaya bahasa pertautan, dan gaya bahasa perulangan. Sementara Gorys Keraf membagi jenis gaya bahasa hanya dalam segi bahasa dan non bahasa.

Sementara itu, penelitian ini akan menggunakan teori gaya bahasa dari Henry Guntur Tarigan. Menurut Tarigan (2013:5) ragam gaya bahasa dibagi dalam empat kelompok, yaitu perbandingan, pertentangan, pertautan, dan perulangan. Masing-masing kelompok gaya bahasa tersebut memiliki jenis-jenis lagi yang memiliki makna lebih khusus. Penggunaan gaya bahasa atau majas pasti memiliki tujuan tertentu, misalnya menegaskan kata-kata penting, kalimat perintah, mengulang kata atau frasa yang dianggap penting (Annisa, 2017)

Menurut (AS Haris Sumadiria, 2017:161) paling tidak terdapat enam jenis feature. Setiap jenis feature tersebut memiliki kekhasannya masing-masing. Yaitu, feature minat insani, sejarah, biografi, perjalanan, petunjuk praktis, dan ilmiah. Adapun menurut (Mappatoto, 1994:56) sebagai acuan pola penulisan feature. terdapat empat gaya bangunan atau pola feature yaitu; gaya piramida terbalik, piramida biasa, segi empat, dan pola piramida kronologis (Mappatoto, 1994:56). Seperti yang juga dijelaskan Sari (2016) gaya bangunan pada struktur feature sama artinya dengan pola struktur feature. Komponen atau struktur bangunan feature dalam penelitian yang dilakukan Sari ini menyebutkan ada empat, yakni judul, intro, tubuh, dan penutup. Berikut ini visualisasi pola-pola yang dimaksud. 

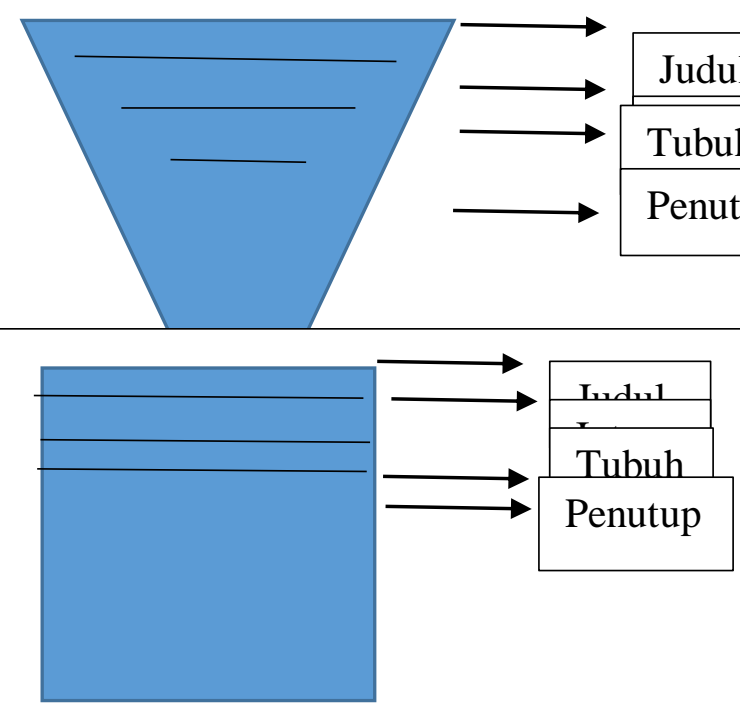

ga

per

panya

engg

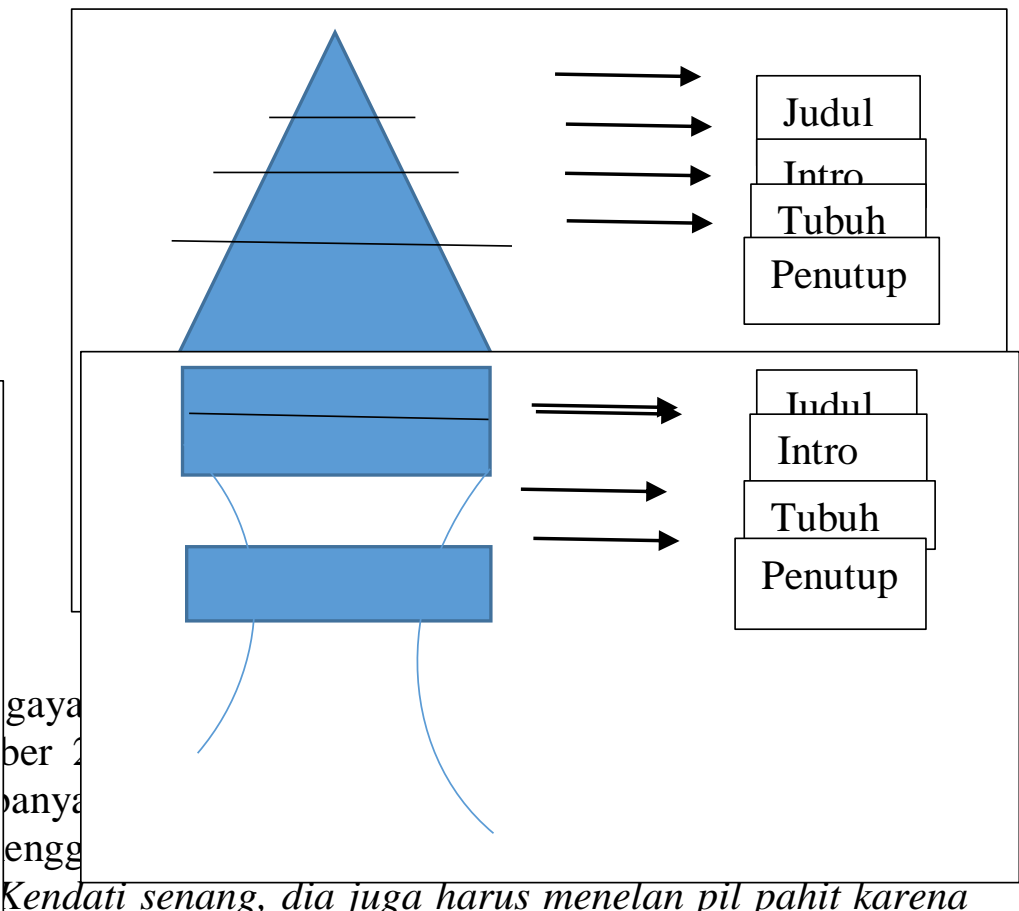

kenllangan mereka. (FIVII.1). DI awal, pada kata kendati senang merupakan penggunaan gaya bahasa perbandingan, jenis antisipasi atau prolepsis. Gaya bahasa ini mengajak pembaca mengetahui keadaan atau rasa yang terjadi sebelum semua gagasan dibaca. Pada kalimat ini pembaca akan mengetahui bahwa suasana yang akan dibangun dalam konteks adalah antara kesenangan bercampur kesedihan.

Selain gaya bahasa di atas, terdapat juga gaya bahasa perbandingan jenis perumpamaan yang terdapat pada kata menelan pil pahit. Makna ini tidak sebenarnya melainkan menggambarkan keadaan yang pahit sehingga diibaratkan seperti meminum pil pahit. Pil dalam makna asli adalah obat atau benda yang jika diminum memberikan efek kepada tubuh. Sedangkan kata pahit menandakan keadaan yang tidak baik. Jadi arti kata pil pahit adalah menelan sesuatu yang tidak baik atau sebuah kemudaratan. Hasil analisis pada pola menunjukkan lebih banyak yang menggunakan pola kronologis. Seperti halnya pada feature ilmiah ke dua (FI.2). Pola Kronologis adalah karangan dengan model tuturan kronologis (Mappatoto, 1994:57). Kronologis berarti urutan sejumlah kejadian berdasarkan waktu. Karangan ini menceritakan kunjungan salah seorang wartawan ke tempat kerja Subekti, mulai dari mengetahui secara umum tentang aplikasi sistem monitoring reaktor nuklir sampai proses pengoperasian. Berikut ini kutipan yang mencirikan bahwa karangan atau berita ini memiliki pola kronologis:

Muhammad Subekti mengajak ke ruang kerjanya di lantai 2. Ruangan itu tidak begitu luas. Di sudut dekat pintu sudah bergerombol mahasiswa magang duduk di meja besar. Di tengahnya ada sejumlah perangkat pemantau reaktor nuklir dan beberapa komputer.

Setelah aplikasi beroperasi, pria kelahiran Madiun, 18 Juli 1973, itu menjelaskan kegunaannya.

Kutipan tersebut menjelaskan kejadian demi kejadian. Pola paragraf sudah jelas yakni spiral karena menggulir ke bawah. Sementara pola rinciannya termasuk susunan logis klimaks. Susunan ini memberikan penekanan paling banyak di akhir paragraf. Melalui trik tersebut membuat berita semakin ke bawah semakin menarik, sehingga pembaca akan dibuat penasaran dan membaca secara keseluruhan.

Melalui analisis panjang, diketahui bahwa bahasa pada feature dalam surat kabar Jawa Pos.com memiliki karakteristik sendiri. Namun, karakteristik itu tidak menghilangkan ciri khas feature yang memiliki unsur human interst. Hasil dan pembahasan penelitian dapat dilihat dalam 
rincian berikut ini. Terdapat empat belas jenis gaya bahasa yang digunakan dalam sebelas feature. Gaya bahasa tersebut adalah Pereumpamaan, Metafora, Personifikasi, Antisipasi atau Prolepsis, Hiperbola, Oksimorom, Zeugma, Metonimia, Antonomasia, Asindeton, Aliterasi, dan Simploke. Jumlah keseluruhan gaya bahasa yang ditemukan adalah lima puluh dengan jumlah masing-masing pada jenis feature yaitu: (1) FMI:8, (2) FS:6, (3) FB: 14, (4) FP:3, (5) FPP:9, dan (6) FI:10. Sementara perolehan jumlah gaya bahasa secara garis besar uraiannya sebagai berikut: (1) Perbandingan:35, (2) Pertentangan:2, (3) Pertautan:10, dan (4) Perulangan:3.

Analisis kedua dalam penelitian ini adalah menemukan pola struktur berita feature atau karangan khas yang ditulis Surat Kabar Jawa Pos.com. terdapat empat pola yang digunakan yaitu pola persegi empat, piramida biasa, piramida terbalik, dan kronologis. Berikut ini hasil analisis dari masingmasing jenis feature: (1) Pola Persegi empat: FM.1, (2) Pola Piramida biasa: FS.1, FS.2, dan FB.2, (3) Pola Piramida Terbalik: FP.1, (4) Pola Kronologis: fm.2, FB.1, FP.2, FPP.1, FI.1, dan FI.2. Jadi, dapat disimpulkan feature ini lebih banyak menggunakan Pola Kronologis. Hasil penelitian disajikan dalam bentuk gambar atau data yang dibuat gambar/grafik/diagram, tabel, dan/atau deskriptif. Penyajian tersebut diiringi dengan analisis dan interpretasi hasil sebelum dibahas pada paragraf selanjutnya.

\section{SIMPULAN}

Hasil dari penelitian memperlihatkan, manusia sebagai pencipta berita memiliki sifat kreatif. Teori yang telah ada bersifat dinamis seiring perkembangan zaman dan kebutuhan manusia. Begitu pula yang terjadi pada feature sebuah karangan khas, banyak kejadian di lapangan yang berbeda dari teori. Namun, tidak sepenuhnya feature yang ada pada surat kabar Jawa Pos.com ini berbeda dengan teori. Seluruh feature yang dianalisis tetap memiliki unsur human interest. Hal ini dapat terlihat dari judul hingga penutup setiap berita feature. Jadi pada intinya teori struktur tidak selalu diterapkan di lapangan, tetapi gaya bahasa tetap digunakan guna memperindah bahasa yang menunjang unsur human interst. Jadi, surat kabar Jawa Pos.com ini memiliki karakteristik sendiri dalam penulisan berita feature.

\section{DAFTAR PUSTAKA}

Annisa. (2017). HUBUNGAN PENGUASAAN GAYA BAHASA PERBANDINGAN SISWA KELAS VII SMP DWI TUNGGAL TANJUNG MORAWA TAHUN, 678, 9-18. https://doi.org/http://dx.doi.org/10.29408/sbs.v1i1.790

AS Haris Sumadiria. (2017). Jurnalistik Indonesia. Bandung: Simbiosa Rekatama Media.

Barus, W. (2010). Jurnalistik Petunjuk Teknis Menulis Berita. Jakarta: Erlangga.

Cahyo, A. N. (2009). Berita Feature Sebagai Metode Dakwah (Studi terhadap Rubrik "Silaturahim" di QA Propetic Parenting Magazine.

Daryanto. (2016). Teori Komunikasi. Yogyakarta: Gaya Media.

Kusumaningrat, H. K. \& P. (2016). Jurnalistik Teori \& Praktik. Bandung.

Mappatoto, A. B. (1994). Teknik Penulisan Feature (2nd ed.). Jakarta: PT Gramedia Pustaka Utama.

Mey, U., \& Zulaeha, I. (2017). Journal Indonesian Language Education and Literature, 3(1), 45-52. https://doi.org/DOI:http://dx.doi.org/10.24235/ileal.v3i1.1570 
Mulyaningsih, I., \& Itaristanti. (2018). Pembelajaran Bermuatan HOTS ( Higher Order Thinking Skill ) di Jurusan Tadris Bahasa Indonesia, 4(1), 114-128. https://doi.org/10.24235/ileal.v4i1.2970

Sari, E. A. E. (2016). Gaya Bahasa dan Struktur Feature Perjalanan Majalah Intisari Edisi Januari 2016.

Sudaryanto. (2015). Metode dan Teknik Analisis Bahasa. Duta Wacana University Press.

Tarigan, H. G. (2013). Gaya Bahasa. Bandung: CV Angkasa. 